\title{
The Most Celebrated Chinese Writer of the Twentieth Century: An Introduction to Lu Xun
}

ISSN: 2311-8636 (Print)

ISSN: 2312-2021 (Online)

Licensed:

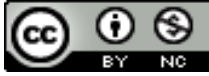

Source of Support: Nil

No Conflict of Interest: Declared

*Email for correspondence:

lwong@sheridan.edu.au

\section{Leei Wong}

Lecturer, Sheridan College, PO Box D178, Perth, WESTERN AUSTRALIA

\section{ABSTRACT}

Over the years, many renowned scholars have done several researches about the great writer, Lu Xun and his works. Much interest is centered on him even today. We will examine here, briefly the reasons that is unique in him that he is hailed "the most celebrated Chinese writer of the twentieth century", through the historical background at that time and his writings.

Keywords: 21st Century, Chinese Literature, Lu Xun

\section{INTRODUCTION}

Over the years, many renowned scholars have done several researches about the great writer, Lu Xun and his works. Much interest is centred on him even today. We will examine here, briefly the reasons that is unique in him that he is hailed "the most celebrated Chinese writer of the twentieth century", through the historical background at that time and his writings.

\section{THE "SOUL OF THE NATION"}

The title given to Lu Xun by his supporters -- the "Soul of the Nation" shows that Lu Xun's deep conviction and sincerity over the nation's future, and his efforts in using literature to attempt to transform his beloved country much appreciated by many. In his preface to 'Call to Arms' the author tells his motive in choosing literature as a 'weapon of struggle'.

\section{THE WRITER's LETHAL WEAPON}

Lu Xun was not a politician, nor a soldier. Nevertheless, he had an effective tool, which was his pen, to 'fight' for his country. During the period of the New Cultural Movement, $\mathrm{Lu}$ Xun began to write his short stories in order to awake the nation. His first vernacular story, 'A Madman's Diary', was published in 'The New Youth' and since then Lu Xun has skilfully utilised his 'weapon' and became a powerful and pivotal voice in pointing the direction for the future of China. 


\section{POWERFUl SOURCE OF INSPIRATION FOR THE FutURE GENERATION}

$\mathrm{Lu}$ Xun felt he had a responsibility in his writing when he said, "I sometimes call out, to encourage those fighters who are galloping on in loneliness, so that they do not lose heart." He placed his hopes in the young people, who are the future of the country. It could be that he could not see the desired changed happening in China or he must have felt the tedious and long process for China to experience real change would need the help of the next generation.

This can been seen towards the end of the story in 'A Madman's Diary', when the 'madman' turned his concern to his late sister, though she had died when she was five, because he was afraid she would be cannibalized. The story ends with a famous line: "Save the children..." with Lu Xun's hope, perhaps, for the young generation to achieve what the present generation could not.

\section{RARE SELF-DISSECTION OF A WRITER}

Lu Xun is very explicit in admitting his own personal flaws as he "dissected himself' more harshly than he ever did to anyone else. For instance, the Bogus-Foreign Devil in 'The True Story of Ah $\mathrm{Q}^{\prime}$ was in fact the image of Lu Xun himself, with his hair without a pigtail and holding a walking stick. Lu Xun was constantly not afraid to laugh at himself which is a very rare characteristic in the Chinese Culture. The self-mocking style comes with much courage in admitting any flaws and the willingness in opening up for any correction. As much as he is dissecting himself, he is also trying to 'dissect' the country.

\section{A Writer-Doctor Diagnosing the Spiritual Illness of China)}

The well-known incident of watching the slide showing Japan caused a complete turn for $\mathrm{Lu}$ Xun's life. A crowd of fellow Chinese were enjoying viewing the slide-show of an execution of a Chinese spy (who worked for the Russians) by the Japanese authority. The disgust and horror he experienced from the fellow Chinese students' indifference, or rather ignorance to the slide-show, had a tremendous impact on him and made him determined to 'transform their spirit'. Lin, in 'The crisis of Chinese consciousness' refers to the students' attitude as 'shallowness' and 'downright hypocrisy. This is similar to Lu Xun's story of the revolutionary in 'Medicine', who was exposed by his own family member. To the readers' horror, the family member even pocketed a nice reward out of the disgusting act. The unfeeling nature of the Chinese towards their own people is criticised by Lu Xun and it shows his detest for such an abolishing act.

Furthermore, in the story "Medicine", Lu Xun's use of the vivid fresh human blood exposes the bloody image of the blood sucking inhumane society and that parallels to the theme in 'A Madman's Diary' cannibalism. And, the idea of consuming a mantou, dipped in fresh blood to cure tuberculosis is absurd but many people still followed suit. The writer is a skilful doctor who cuts right through to the decayed parts of China, exposing the wounds for the rest to view.

With regards to Lu Xun's change of mind about his own future, one might think that it was an impulsive act of the young Lu Xun or we might think of the impracticality of making such a drastic change, from aspiring to be a doctor to actually becoming a writer. However, we could tell that he was prepared, with much conviction to contribute to society. His determination could have been influenced by Sun Yat-Sen's, inferring from his life story, where he also gave up his medical profession for his country, but as a revolutionary to heal the nation, instead of just healing patients. 
Lu Xun, like Sun, has abandoned his chance of becoming a doctor, and he also felt that he had a greater sense of responsibility, of becoming the nation's doctor. Even though he could not fully cure the nation, he tried his best to diagnose the problems and encourage everyone to come face to face with the flaws of the society. The purpose to encourage in his writing can be found in the 'A Madman's Diary', when the madman assumes a prestigious role at the top of the feudalist society, knowing that it was a type of cannibalism. The episode is supposed to incite anger in the readers and encourage them to push forward for real changes in their country. Lu Xun is seen as a doctor, who is able to diagnose the country's 'spiritual sickness"' and trying his best to seek remedies as far as he could.

\section{An Eye-Witness in China History}

The stories of Lu Xun are linked with the history and politics of his time and without an understanding of the history, Lu Xun's wit and sarcasm is hard to understand. Julia Lovell, a translator of Lu Xun's work, comments that "to read $\mathrm{Lu}$ Xun is to capture a snapshot of late imperial and early Republican China".An example is that the revolutionary in the story 'Medicine' actually refers to Qiu Jin, the real anti-Qing revolutionary, who was arrested, tortured and killed. The blood on the mantou in 'Medicine' actually refers to the blood of Qiu Jin.

In a way, Lu Xun was a witness of the historical events and he was recording history through his writings, even though he himself did not really approve of the way the revolutionary should act (as he thought that the sacrifice was unnecessary and could have been avoided). Nevertheless, it was an episode in China history that must be addressed and through Lu Xun's writings, we will ponder over and remember these episodes.

There are also many examples, like the case of $A h Q$, that we could visualise China history before our eyes. Ah Q's social status is also illuminative in describing China's status in the international stage. Ah $\mathrm{Q}$ repeatedly got into fights and never won, but he tried to come out with silly reasons to convince himself that he was always victorious. This is likened to China, which seemed to always have an extreme pride of herself; too strong to admit the constant defeats she experienced and ignoring the facts of reality. The stubbornness and ignorance in Ah Q's character also pinpoints the social problems and the old Chinese society because Ah $Q$ did not want to accept change, which eventually leads to his decapitation at the end of the story. This is in a way likened to the collapse of the Qing Dynasty.

\section{Understanding History through Lu XUn / Understanding LU Xun THROUGH HISTORY}

Lu Xun is observant and hit the nail right on the head on society's ugliness and plagues. He understands the passivity of the people and hints at people to stop evading problems in the country, and to take up the responsibility, as members of the society. He must have felt that the strength of the nation to come together and challenge the epidemics of the country face to face was crucial.

$\mathrm{Lu}$ Xun's fiction demonstrates the tumultuous times in Chinese history and served as a direction for the people in those difficult times. As for readers of later times, we need to have an understanding of the historical references, then we can appreciate Lu Xun's works and find his stories fascinating. The history of China is portrayed to us through Lu Xun, in a painful way, making readers feel, weep and ponder over history as not merely a series of events. We have to understand the social background at that time in order to grasp Lu Xun's messages behind his stories. 
On the other hand, without the understanding of Lu Xun, it is not easy to comprehend China of that period. Lu Xun was one of the rare writers who feels and weeps and was proactive in the developmental aspects of Chinese history, literature and culture, and we could perceive that his life is closely linked to the cultural as well as ideological implications in China. Lu Xun's stories become especially poignant because of their relation to changes in China. In fact, most contemporary foreign scholars, or anyone interested in the study of China might even gain an insight on China through the works of Lu Xun.

\section{Pioneer in Modern Chinese Literature-Literary Reform}

$\mathrm{Lu}$ Xun was a proponent of writing in vernacular Chinese and he was the first ever in China history who experimented with Western-style short story written in vernacular Chinese. In his "A Madman's Diary", Lu Xun saw classical Chinese as the main obstacle to promote literacy throughout China, and he also saw the vitalness for a language reform as a means to push for modernization.

His ingenious way of using vernacular and classical Chinese in the story as "a political comment on the ethics of traditional culture" is unique and he is vastly recognized today as a key contributor to Chinese language reform as he has produced actual results in his unparalleled style of creating modern literature. The foundation for modern Chinese literature has been successfully laid down and Lu Xun has contributed greatly to the identity of modern Chinese literature.

The courage to lead by example in changing the conventional way of writing using classical Chinese to "baihuawen" must have upset many traditionalists at that time. Lu Xun saw it as a means for more people to communicate ideas, perhaps due to his own experience. For instance, in 'My Old Home', there is sense of uneasiness when his childhood playmate Runtu addressed him as 'Master' when they met later in life. 'A shiver ran through' he and a 'thick wall has grown up' between them shows that he was sorry to see Runtu's plight and also that there is a sense of regret for the social disparity between them. Writing in vernacular is a way of bridging the gap of social inequality through the exchange of ideas in a simple and more direct way.

\section{Writer Able to Articulate the Inner Thoughts of the Public}

Lu Xun was unafraid to voice out the thoughts representing the people, as in those times, he might be arrested and persecuted for being too 'outspoken' in his writings. The topics that he explored have never really been openly discussed, but they were at the back of the minds of people, especially the young. For example, the status of women in society is a topic the conservative Chinese society would shy away from. The sufferings of Xianglin's Wife portrayed in 'The New Year Sacrifice' like 'malicious and salacious gossip' and 'rejection by her employers' clearly show that women are discriminated again, especially widows. It is anti-traditional in the sense that some characters portrayed in his stories are extremely heartless; unfeeling; bound to tradition; cannibalistic, which the Chinese people are aware of but always in self-denial. He articulates the inner voice of people aloud, proclaiming his stance instead of just being a passive bystander like many people in the country.

\section{Unique, Captivating Literary Style}

Lu Xun's 'stylistic innovations' in writing could be difficult for the modern-day reader to comprehend, not only because of the historical background, but of his superb literary style of writing. We could sense the gloomy atmosphere in the stories, yet, they also come with 
witty expressions. The apt metaphors used and vivid, specific examples are persuasive and full of artistic appeal. He 'drew on traditional artistic techniques' but his "creative form is different from traditional Chinese literature". His talent in writing has undoubtedly facilitated the ideas he wanted to bring forward effectively.

His works could be viewed as offensive for readers and provocative as he is always against the Chinese tradition. He created a sensation with the condemnation of Confucian culture; the way he saw traditional Chinese medicine as ineffective means used by quack doctors or cheats to deceive ignorant people, and the ways he portrayed the dysfunctional society, could be too repulsive for certain readers. Also, a tone of exaggeration may be detected as he expresses his strong ideas across bluntly. For instance, the offering of ' a threshold in the Temple of the Tutelary God" mentioned in 'The New Year Sacrifice' was directing at the people at that time, and one would wonder how they would have felt when they knew that $\mathrm{Lu}$ Xun was directly pointing at their useless ways trying to mitigate life's miseries.

\section{CONCLUSION}

In the early 1950s, Takeuchi Yoshimi (1910-1977), a main scholar in Japan who studied about Lu Xun claims that Lu Xun's 'thought and literature constituted, in essence, a sharp critique of Japan', Through his works, some of the Japanese people found the strength to rejuvenate their politically crumbling country. Today, we see Lu Xun as an international recognised writer with his works translated into as many as twenty-four different languages. His literature and thought still receives great attention and his popularity does not restrict solely to China or Chinese people. It is heartening to know that the study of Lu Xun has actually drawn people together and goes beyond national boundaries.

We know that Lu Xun did not write for the sake of literature. His writings have deeper insights and his desire of making literature relevant to everyone, at the same time transform China is commendable. This aspect of Lu Xun as a writer is unique and remains unparallel in Chinese history. The efforts of the patriotic writer who truly feels and weeps for the nation, is still valuable in the 21st century, and Lu Xun is still much discussed about and much debated over even until the present day. He is definitely the most celebrated Chinese writer of the twentieth century, or perhaps also in the twenty-first century.

\section{REFERENCES:}

Chinese media, advertising, and urban life. (n.d.). Retrieved January 24, 2017, from http://www.danwei.org/translation/julia_lovell_complete_lu_xun_f.php

Former Residence of Lu Xun. (n.d.). Retrieved January 24, 2017, from http:/ / www.china.org.cn/english/features/beijing/31049.htm

Goldman, M., \& Lee, L. O. (2002). An intellectual history of modern China. New York: Cambridge University Press.

Gunn, E. M. (1991). Rewriting Chinese: style and innovation in twentieth-century Chinese prose. Stanford, CA: Stanford University Press.

Lee, L. O. (1985). Lu Xun and his legacy. Berkeley: University of California Press.

Lin, Y. (1979). The crisis of Chinese consciousness: radical antitraditionalism in the May Fourth era. Madison: University of Wisconsin Press.

Pollard, D. (2002). The true story of Lu Xun. Hong Kong: The Chinese University Press.

Preface to Call to Arms. (n.d.). Retrieved January 24, 2017, from http://www.marxists.org/archive/lu-xun/1922/12/03.htm 
Sharman, L. (1968). Sun Yat-sen; his life and its meaning; a critical biography. Stanford, CA: Stanford University Press.

Spence, J. D., \& Wen, Q. (2007). Tian'anmen: Zhongguo de zhi shi fen zi yu ge ming = The gate of heavenly peace: the Chinese and their revolution, 1895-1980. Taibei Shi: Shi bao wen hua chu ban qi ye gu fen you xian gong si.

Yoshimi, T. What is Modernity?, Columbia University Press, 2005 - History - 182 pages

$$
--0-
$$

Publish Online and Print Version Both

Online ISSN: 2312-2021

Google Scholar: https://goo.gl/eozEWi 